\title{
The Effect of Glutamine Supplementation to Fecal Calprotectin and Tumor Necrosis Factor- $\alpha$ Levels in the Fecal of Rats with Acute-Induced Diarrhea
}

\author{
Deddy Satriya Putra ${ }^{1}$, Fadil Oenzil², Eryati Darwin ${ }^{3}$, Hafni Bachtiar ${ }^{4}$ \\ ${ }^{1}$ Doctoral Student of Postgraduate Biomedical Science, Faculty of Medicine, Andalas University, Padang, Indonesia; \\ ${ }^{2}$ Department of Nutritional Science, Faculty of Medicine, Andalas University, Padang, Indonesia; ${ }^{3}$ Department of Histological \\ Science, Faculty of Medicine, Andalas University, Padang, Indonesia; ${ }^{4}$ Department of Public Health, Faculty of Medicine, \\ Andalas University, Padang, Indonesia
}

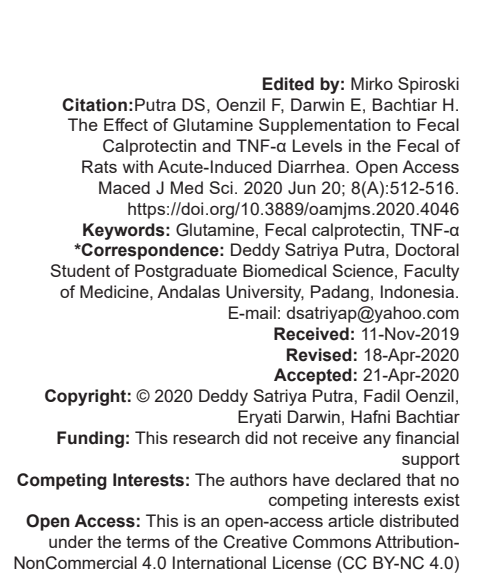

\section{Abstract}

BACKGROUND: Glutamine is a non-essential amino acid as the main fuel in the gastrointestinal mucosa. By its various gastrointestinal functions, glutamine is thought to increase the protection of the intestinal mucosa against local or systemic injury from diarrhea.

AIM: This study aimed to determine the relationship between glutamine supplementation and fecal calprotectin and tumor necrosis factor- $\alpha$ (TNF- $\alpha$ ) in the fecal of rats with acute and chronic diarrhea induced by EPEC.

MATERIALS AND METHODS: The research was conducted in an experimental laboratory with a randomized posttest only control group design. A total of 30 Rattus norvegicus strain Wistar were divided into five groups. The treatment group was induced to have diarrhea using EPEC at a dose of $108 \mathrm{CFU} / \mathrm{ml}$, after each group diagnosed by acute and chronic diarrhea, followed by glutamine supplementation at a dose of $810 \mathrm{mg} / 200 \mathrm{~g}$ for 14 days. The inflammatory cytoknies which is fecal calprotectin and TNF- $\alpha$, of each group was assessed and the $p$ value was measured by one-way ANOVA and post hoc Bonferroni test to find out the relationship between these variables.

RESULT: Supplementation of glutamine for 14 days can reduce fecal calprotectin levels in chronic diarrhea and reduce TNF- $\alpha$ level in rats with acute and chronic diarrhea.

CONCLUSION: Glutamine supplementation has an effect on the fecal calprotectin and TNF- $\alpha$ of rats with acute and chronic diarrhea.

\section{Introduction}

Diarrhea is a condition in which tools are passed with a watery consistency that usually occurs with a frequency of more than 3 times/day [1]. Diarrhea is a major cause of morbidity and mortality in children worldwide, where $98 \%$ of deaths occur in developing countries, including Indonesia [2], [3]. Results of the 2013 Indonesian Basic Health Research stated in Riau Province, diarrhea was the second most common cause of toddlers' mortality, accounting for $17.2 \%$ of all toddler deaths [4].

Glutamine is a non-essential amino acid with an abundant amount in the human body. In the gastrointestinal tract, glutamine is known as the main fuel of the intestinal mucosa that triggers enterocyte growth, increases intestinal barrier function, and increases blood circulation to the intestine, plays an important role in the synthesis of nucleic and amino acids in the intestinal barrier, maintains integrity of the tight junction, and acts as an immunomodulator. Glutamine is produced by the body in sufficient quantities, but its use tends to increase during illness including diarrhea, which causes glutamine depletion. This condition will interfere with the functions of glutamine and aggravate an illness. Diarrhea will be followed by damage to the intestine, and glutamine deficiency will inhibit its repair. Therefore, the supplementation of exogenous glutamine is needed to help the regeneration of damaged intestinal mucosa [5].

The benefits of glutamine as an adjuvant in managing diarrhea have been obtained based on several studies. A study by Radha and Samak and Vicario et al. and Carneiro-Filho et al. showed that glutamine has protective properties for mucosal barriers because of its effects on maintaining the integrity of intestinal epithelial tight junction cells [6], [7], [8]. In addition, glutamine could also facilitate enteral absorption of nutrients and electrolytes in diarrhea and reduce the severity of diarrhea by increasing water and salt uptake [9].

Based on a previous study, glutamine can improve intestinal growth, promote enterocyte proliferation and survival, and regulate the intestinal 
barrier function during injury, infection, stress, and catabolic conditions. This effect occurs because glutamine can maintain intracellular redox status and regulate gene expression associated with various signaling pathways [10]. Research from Roedi Irawan also supported that glutamine could repair ileal microvilli in malnourished rats. In addition, an increase in intestinal enzyme activity, namely, sucrase, maltase, lactase, spectrin, as well as clathrin was found. This growing evidence supports the idea that glutamine is beneficial for intestinal repair [11]. Furthermore, a study by Huang showed the beneficial of glutamine on improvement of Rattus norvegicus strain Wistar's intestinal that is experiencing chronic diarrhea [12]. However, different results are shown from study by Kamucakhi about the benefits of glutamine supplementation in children who experience chronic diarrhea, in which glutamine supplementation showed no useful results [13]. This study aimed to determine the relationship between glutamine supplementation and fecal calprotectin, slgA, TNF- $\alpha$ in the fecal of rats with acute and chronic diarrhea induced by EPEC.

\section{Materials and Methods}

This study was conducted in an experimental laboratory study using a randomized post-test only control group design.

\section{Experimental samples}

The sample of this study consisted of male rats (Wistar strain of Rattus norvegicus) aged 10-16 weeks, with a body weight of 160-250 g. The samples were divided into five groups with six rats/group: Negative control group $(K)$, acute diarrhea group $(A)$, acute diarrhea group supplemented with glutamine (Kyowa Hakko Bio Co., Made in Japan) at a dose of $810 \mathrm{mg} / 200 \mathrm{~g}$ rat (B), chronic diarrhea group (C), and chronic diarrhea group supplemented with glutamine at a dose of $810 \mathrm{mg} / 200 \mathrm{~g}$ rat (D). The dose of glutamine given to the rats was based on the human-to-animal dose conversion factors. The dose in humans is $45 \mathrm{mg} /$ day at a body weight of $70 \mathrm{~kg}$, converted into $0.018 \mathrm{mg} /$ day for rat.

\section{Experimental design}

Rats are placed in plastic cages with a lid made of ram wire and are given a filter paper mat to observe rats faces. The pad is replaced 3 times a week. The cage is placed in a well-ventilated room with good air circulation. The environment of cage is made so that it is not humid, the temperature of the cage is maintained according to room temperature $\left(20-26^{\circ} \mathrm{C}\right)$, and the exchange of dark and light every $12 \mathrm{~h}$. Each rat is placed in its own cage. All rats are giving food and drink is given ad libitum and monitored its health every day. Acute diarrhea was induced in Groups A and B using EPEC (2 ml with a population of $108 \mathrm{CFU} / \mathrm{ml})$. Chronic diarrhea was induced in Groups C and D using EPEC (2 ml with a population of $108 \mathrm{CFU} / \mathrm{ml}$, given doses of repetition every 3 days). Diarrheic rats in Groups $A$ and $C$ were given the standard feeding, while those in Groups B and $D$ were given glutamine for 14 days at a dose of $810 \mathrm{mg} / 200 \mathrm{~g} /$ day as soon after diagnosed by acute and chronic diarrhea. On the $15^{\text {th }}$ day after standard feeding and glutamine supplementation, glutamine is given at a dose of $810 \mathrm{mg} / 200 \mathrm{~g}$ which is dissolved with aqua as much as $4 \mathrm{ml}$ orally using sonde every day for 14 days. The rats' feces were taken from the ileum, weighing $15 \mathrm{mg}$ for $100 \mu$ l PBS.

\section{Fecal calprotectin analysis}

Fecal calprotectin levels were analyzed according to the instruction manual on the rat calprotectin ELISA Kit. Feces/stool taken from the caecum is centrifuged for $20 \mathrm{~min}$ at a speed of $5000 \mathrm{rpm}$. Supernatants are carefully taken, the sample can be stored at $-20^{\circ} \mathrm{C}$ or $-80^{\circ} \mathrm{C}$. Before the examination is carried out, the sample is placed at room temperature $\left(18^{\circ} \mathrm{C}-25^{\circ} \mathrm{C}\right)$ for $30 \mathrm{~min}$. Next prepare the standard well, sample well, and blank well. Standard solutions, samples, and blanks of $100 \mu$ l were put into each well on the plate, and then the plate was closed and incubated at room temperature for $1 \mathrm{~h}$. The solution is well aspirated, and then the plate is washed up to three times with wash solution. Then, $50 \mu \mathrm{l}$ of chromogen Reagent A solution is added to each well and re-incubated for $15 \mathrm{~min}$ at room temperature, keeping the plate closed in the dark. Next $50 \mathrm{ml}$ of chromogen Reagent B solution was added and incubated for $15 \mathrm{~min}$ at room temperature. The plates are washed 5 times, then $90 \mu$ substrate solution (Tetramethylbenzidine) is added to each well and incubated for $10 \mathrm{~min}$ at room temperature in a dark room (the liquid will turn blue). After $10 \mathrm{~min}, 50 \mu \mathrm{l}$ of stop solution (sulfuric acid) is added to each well (the liquid will turn yellow), then read on a microplate reader with a wavelength of $450 \mathrm{~nm}$.

\section{Fecal TNF-a level analysis}

TNF- $\alpha$ levels were analyzed according to the instruction manual on the TNF- $\alpha$ ELISA Kit Rat. Stool taken from the caecum is centrifuged for $20 \mathrm{~min}$ at a speed of $5000 \mathrm{rpm}$. Supernatants are carefully taken, the sample can be stored at $-20^{\circ} \mathrm{C}$ or $-80^{\circ} \mathrm{C}$. Before the examination is carried out, the sample is placed at room temperature $\left(18^{\circ} \mathrm{C}-25^{\circ} \mathrm{C}\right)$ for $30 \mathrm{~min}$. Next prepare the standard well, sample well, and blank well. Standard solutions, samples, and blanks of $100 \mu$ l were 
put into each well on the plate, and then the plate was closed and incubated at room temperature for $1 \mathrm{~h}$. The solution is well aspirated, and then the plate is washed up to 3 times with wash solution. Then, $50 \mu$ of the detection Reagent A solution is added to each well and re-incubated for $15 \mathrm{~min}$ at room temperature, keeping the plate closed in the dark. Next $50 \mathrm{ml}$ of detection Reagent $B$ solution was added and incubated for $15 \mathrm{~min}$ at room temperature. The plates are washed 5 times, then $90 \mu \mathrm{l}$ substrate solution (Tetramethylbenzidine) is added to each well and incubated for $10 \mathrm{~min}$ at room temperature in a dark room (the liquid will turn blue). After $10 \mathrm{~min}, 50 \mu \mathrm{l}$ of stop solution (sulfuric acid) is added to each well (the liquid will turn yellow), then read on a microplate reader with a wavelength of $450 \mathrm{~nm}$.

\section{Statistical analysis}

Statistical analysis was performed with SPSS version 19. The sample was tested to determine different effect of glutamine on fecal calprotectin and TNF- $\alpha$ in acute and chronic diarrhea rats, one-way ANOVA test was used, if it was obtained $p<0.05$ followed by post hoc Bonferroni test.

\section{Research ethics requirements}

This study has obtained ethical approval from the Faculty of Medicine, University of Riau (15.3/ UN19.5.1.1.8/UEPKK/2018).

\section{Results}

Fecal calprotectin and TNF- $\alpha$ were assessed on day 15 after glutamine supplementation, in the $\mathrm{K}$ group (negative control), A group (rats with acute diarrhea not given glutamine), B group (rats with acute diarrhea given glutamine supplementation), C group (rats with chronic diarrhea not given glutamine), and D group (rats with chronic diarrhea given glutamine supplementation). Furthermore, an analytical test using the one-way ANOVA method is presented in Table 1.

Tabel 1: Effect of glutamine administration on the mean levels of fecal calprotectin in rats on acute diarrhea group

\begin{tabular}{llll}
\hline Group & $\mathrm{n}$ & $\mathrm{Mean}(\mathrm{SD}) \mu \mathrm{g} / \mathrm{ml}$ & $\mathrm{p}$ \\
\hline $\mathrm{K}$ & 6 & $62.379(8.45)$ & 0.107 \\
$\mathrm{~A}$ & 6 & $74.723(11.76)$ & \\
$\mathrm{B}$ & 6 & $72.130(9.11)$ & \\
\hline K: Control, A: Acute diarrhea, B: Acute diarrhea + glutamine &
\end{tabular}

Table 1 shows that there were differences in the mean levels of fecal calprotectin between rats in Groups K, A, and B. The rates of fecal calprotectin increased in rats in Group A, namely, acute diarrhea rats $(74.723 \mu \mathrm{g} / \mathrm{ml})$ compared with rats in Group B, namely, acute diarrhea rats with glutamine administration
$(72.130 \mu \mathrm{g} / \mathrm{ml})$, and are higher than the average level of fecal calprotectin in Group $\mathrm{K}$ rats, namely, the control group rats $(62.379 \mu \mathrm{g} / \mathrm{ml})$. However, statistically obtained $p>0.05$, so it can be concluded that there is no significant difference from the average fecal calprotectin levels in acute diarrhea group rats.

Table 2 shows that there were no significant differences in the fecal calprotectin levels of Groups K and $A$ rats with $p>0.05$. There were no significant differences in the fecal calprotectin levels in Groups K and $B$ rats as well as in rats Group A and B with $p>0.05$. It can be concluded that the difference in fecal calprotectin levels in each acute diarrhea group was not statistically significant.

Table 2: Effect of glutamine administration on fecal calprotectin levels in each rats on acute diarrhea group

\begin{tabular}{llll}
\hline Group & $\mathrm{K}$ & $\mathrm{A}$ & $\mathrm{B}$ \\
\hline $\mathrm{K}$ & - & 0.141 & 0.324 \\
$\mathrm{~A}$ & 0.141 & - & 1.000 \\
$\mathrm{~B}$ & 0.324 & 1.000 & - \\
\hline $\mathrm{K}$ : Control, A: Acute diarrhea, B: Acute diarrhea + glutamine & &
\end{tabular}

Table 3 shows that there were differences in the mean TNF- $\alpha$ levels between Group K, A, and B rats. There was an increase in TNF- $\alpha$ mean in Group $A$ $(223.878 \mu \mathrm{g} / \mathrm{ml})$ and Group B $(229.382 \mu \mathrm{g} / \mathrm{ml})$ compared to Group K rats $(161.358 \mu \mathrm{g} / \mathrm{ml})$. Group A is lower than Group B. Statistically obtained $p<0.05$ so that it can be concluded that there is a significant difference in the mean TNF- $\alpha$ levels in rats in the acute diarrhea group. Furthermore, to find out the significant differences in each group, an analysis using post hoc Bonferroni is presented in Table 4.

Table 3: Effect of glutamine administration on the mean levels of TNF- $\alpha$ in the rats on acute diarrhea group

\begin{tabular}{llll}
\hline Group & $\mathrm{n}$ & Mean $(\mathrm{SD}) \mu \mathrm{g} / \mathrm{ml}$ & $\mathrm{p}$ \\
\hline $\mathrm{K}$ & 6 & $161.358(26.68)$ & 0.016 \\
$\mathrm{~A}$ & 6 & $223.878(52.29)$ & \\
$\mathrm{B}$ & 6 & $229.382(34.69)$ & \\
\hline K: Control, A: Acute diarrhea, B: Acute diarrhea + glutamine &
\end{tabular}

Table 4 shows that there were significant differences in the TNF-a levels of rats in Groups $\mathrm{K}$ and $A$ and in rats in Groups $K$ and B with $p<0.05$. There was no significant difference in TNF- $\alpha$ levels in rats Group A and B with $p>0.05$. It can be concluded that the differences in the TNF- $\alpha$ levels of rats in Groups K and $A$ and Groups $K$ and $B$ are statistically significant.

Table 4: Effect of glutamine administration on TNF- $\alpha$ levels in each rats on acute diarrhea group

\begin{tabular}{llll}
\hline Group & $\mathrm{K}$ & $\mathrm{A}$ & $\mathrm{B}$ \\
\hline $\mathrm{K}$ & - & $0.045^{\star}$ & $0.027^{*}$ \\
$\mathrm{~A}$ & $0.045^{\star}$ & - & 1.000 \\
$\mathrm{~B}$ & $0.027^{\star}$ & 1.000 & - \\
\hline K: Control, A: Acute diarrhea, B: Acute diarrhea + glutamine & &
\end{tabular}

\section{Discussion}

In this study was shown an increase in levels of fecal calprotectin in rats in the acute diarrhea group and acute diarrhea with glutamine. This shows the 
occurrence of inflammation in the intestinal cells of experimental rats induced by EPEC. Fecal calprotectin can be used as a biomarker for inflammation of intestinal cells and increases significantly in diarrhea due to bacterial infection. High fecal calprotectin levels also correlate with the clinical severity of infectious diarrhea in children, the more severe the clinical, and the higher the fecal calprotectin; therefore, fecal calprotectin can be used as a marker for inflammation in the intestine and as an evaluation of therapeutic management [14].

Although in this study the levels of fecal calprotectin in acute diarrhea rats given glutamine were lower than those in diarrhea rats that were not given glutamine, which suggests that glutamine might have the effect of reducing inflammation, statistically this was not significant. The previous studies conducted by VidalCasariegot (2013), also found no significant difference in calprotectin levels after glutamine administration to prevent enteritis in patients on radiotherapy [15], although the pathophysiology of the study was different.

Calprotectin is a protein complex found in mammals. In the presence of calcium, calprotectin can inhibit the transition from manganese and zinc through the mechanism of chelation, this mechanism (inhibiting the transition from manganese and zinc) is an attempt to kill bacteria in innate immunity; therefore, calprotectin is known to have an antimicrobial function. Calprotectin is mostly (up to $60 \%$ ) present in dissolved proteins in cytosols and neutrophils, although it can be found in monocytes, macrophages, and squamous epithelial cells [16]. Secretion from calprotectin will increase in the inflammatory response. Calprotectin can be found in the intestinal lumen through several mechanisms including increased effects of leukocytes, active secretion, cell disruption, and cell death. As a result, there is an increase in fecal calprotectin levels, which can be detected in feces. An increase in fecal calprotectin indicates there is migration of neutrophils into the intestinal mucosa, due to intestinal inflammation [17].

The results of this study indicate that statistically there are significant differences in the TNF-a group of acute diarrhea. These results differ from the previous studies conducted by Ameho in 1997, which showed glutamine can suppress TNF- $\alpha$ in colitis-induced rats, where the average TNF- $\alpha$ concentration in the group given glutamine was $4 \%$ and $2 \%$ lower than in the control group, the concentration this low level indicates the role of glutamine in inhibiting the synthesis, release, and action of pro-inflammatory cytokines which have an impact on the clinical improvement of the disease [18].

This average difference might occur because there are different glutamine doses, in which in this study a dose of $810 \mathrm{mg} / 200 \mathrm{~g}$ of rats $(4.05 \mathrm{~g} / \mathrm{kg})$ was used, whereas the study from Ameho used a higher dose of $40 \mathrm{~g} / \mathrm{kg} /$ day and a dose of $20 \mathrm{~g} / \mathrm{kg} /$ day. Research from Ameho also shows better results from groups of rats with higher doses than lower ones [18]. Research from
Yalcin in 2004 , with low doses $(0.3 \mathrm{~g} / \mathrm{kg})$ also found no benefit of glutamine immunologically [19].

In this study also found levels of TNF- $\alpha$ in Groups A and B there were no statistically significant differences. This was also found in Ameho, where in the control group and the treatment group, although there were clinical differences, the difference in TNF- $\alpha$ was not statistically significant. Research from Ameho has not yet found an explanation for this, however, it is well known that the serum concentration of TNF- $\alpha$ is not always consistent with the severity of the disease being low [18].

The results of this study are consistent with the previous studies conducted by Ameho in 1997, which showed glutamine can suppress TNF- $\alpha$ in colitisinduced rats, where the average TNF- $\alpha$ concentration in the group given glutamine was $4 \%$ and $2 \%$ lower than the control group, this low concentration indicates the role of glutamine in inhibiting the synthesis, release, and action of pro-inflammatory cytokines, which have an impact on the clinical improvement of the disease [18].

In the early stages of infection, activation of the inflammatory reaction occurs. NF- $\mathrm{KB}$, which is a multiprotein complex, composed of p50, p52, p65, RelB, and c-Rel. In good health, NF-KB is stored in the cytoplasm and remains inactive with the help of an inhibitor of $\mathrm{KB}(\mathrm{I}-\mathrm{kB})$. In response to extracellular stimulus, I-KB kinase performs phosphorylation of the $\mathrm{I}-\mathrm{KB}$ protein, resulting in $\mathrm{I}-\mathrm{KB}$ degradation which causes the release and activation of NF-KB. This active NF-KB complex then moves into the nucleus and induces expression of the NF-kB-binding element gene, such as IL-6 and TNF- $\alpha$. In this inflammatory state, production of IL- 6 and TNF- $\alpha$ increases rapidly, which stimulates immune responses, such as antigen-presenting cells and T-cells [10].

Glutamine predicted to inhibit these pathways with multimodal. There are several mechanisms by which glutamine can suppress TNF- $\alpha$, including inhibition of IKBa-ubiquitination, inhibition of activation of NF-kB, which has an impact on suppressing the production of IL-6, IL-8, and TNF- $\alpha$, and reducing regulation of signal transducers and activators of transcription (transcription). The previous studies have shown that glutamine supplementation can be a promising candidate for treating this inflammatory disease [10]. Supplementation of glutamine for 14 days can reduce fecal calprotectin levels in chronic diarrhea and reduce TNF- $\alpha$ level in rats with acute diarrhea.

\section{Acknowledgment}

We would like to thank PT Novel Pharmaceutical Laboratories Indonesia for providing the glutamine powder from Japan. 


\section{References}

1. Sumarso P. Buku Ajar IImu Kesehatan Anak: Infeksi Dan Penyakit Tropis. Indonesia, Jakarta: Ikatan Dokter Anak; 2003.

2. Randy PP, Russell WS. Pediatric Gastroenteritis. Pediatric: General Medicine, Medscape; 2016.

3. Komarulzaman A, Smits J, de Jong E. Clean water, sanitation and diarrhoea in Indonesia: Effects of household and community factors. Glob Public Health 2017;12(9):1141-55. https://doi.org/ 10.1080/17441692.2015.1127985

PMid:26758565

4. Profil Kesehatan Provinsi Riau. Dinas Kesehatan Provinsi Riau; 2012. https://doi.org/10.31227/osf.io/bja4k

5. Duggan C, Gannon J, Walker WA. Protective nutrients and functional foods for the gastrointestinal tract. Am J Clin Nutr. 2002;75(5):789-808. https://doi.org/10.1093/ajcn/75.5.789 PMid:11976152

6. Radha R, Samak G. Role of glutamine in protection of intestinal epithelial tight junctions. J Epithelial Biol Pharmacol. 2012;5(Suppl):47-54. https://doi. org/10.2174/1875044301205010047

PMid:25810794

7. Vicario M, Amat C, Rivero M, Moretó M, Pelegrí C. Dietary glutamine affects mucosal functions in rats with mild DSSinduced colitis. J Nutr. 2007;137(8):1931-7. https://doi. org/10.1093/jn/137.8.1931

PMid:17634266

8. Carneiro-Filho BA, Bushen OY, Brito GA, Lima AA, Guerrant RL. Glutamine analogues as adjunctive therapy for infectious diarrhea. Curr Infect Dis Rep. 2003;5(2):114-9. https://doi. org/10.1007/s11908-003-0046-2

PMid:12641996

9. Xue H, Sawyer B, Field C, Dieleman LA, Murray D, Baracos VE. Bolus oral glutamine protects rats against CPT-11-induced diarrhea and differentially activates cytoprotective mechanisms in host intestine but not tumor. J Nutr. 2008;138(4):740-6. https://doi.org/10.1093/jn/138.4.740 PMid:18356329

10. Kim MH, Kim H. The roles of glutamine in the intestine and its implication in intestinal diseases. Int $\mathrm{J}$ Mol Sci. 2017;18(5):18051051.

PMid:28498331
11. Irawan R, Subijanto MS, Putra S, Soetjipto S. Efek pemberian glutamin terhadap aktivitas sucrase, maltase, lactase dan ekspresi spectrin, clathrin dalam perbaikan mikrovili ileum pada tikus malnutrisi. JBP. 2012;14(1):568.

12. Huang ZX, Ye LY, Zheng ZY, Chen XM, Ren RN, Tong GY. Effect of glutamine on small intestinal repair in weanling rats after chronic diarrhea. Zhonghua Er Ke Za Zhi. 2005;43(5):368-72. PMid: 15924756

13. Kamuchaki J, Wobodeya E, Kiguli S, Bortolussi R. Efficacy of glutamine supplementation on the outcome of children admitted with persistent diarrhea in Uganda: A randomized controlled study. Paediatr Child Health. 2013;18(1):e1. https:// doi.org/10.1093/pch/18.1.e1

14. Chen CC, Huang JL, Chang CJ, Kong MS. Fecal calprotectin as a correlative marker in clinical severity of infectious diarrhea and usefulness in evaluating bacterial or viral pathogens in children. J Pediatr Gastroenterol. Nutr. vol. 55, no. 2012;5:541-7. https:// doi.org/10.1097/mpg.0b013e318262a718 PMid:22699836

15. Vidal-Casariego A, Calleja-FernandezA, de Urbina-Gonzales JJ, Cano-Rodríguez I, Cordido F, Ballesteros-Pomar MD. Efficacy of glutamine in the prevention of acute radiation enteritis: A randomized controlled trial. J Parenteran Enteral Nutr. 2014;38(2):205-13. https://doi.org/10.1177/0148607113478191 PMid:23471208

16. Striz I, Trebichavsky I. Calprotectin-a pleiotropic molecule in acute and chronic inflammation. Physiol Res Acad Sci Bohemoslovaca. 2004;53(3):245-53. PMid:15209531

17. Gupta R. Biomarkers in Toxicology. San Diego, CA: Academic Press; 2014. p. 272-3.

18. Ameho CK, Adjei A, Harrison E, Takeshita K, Morioka T, Arakaki $\mathrm{Y}$, et al. Prophylactic effect of dietary glutamine supplementation on interleukin 8 and tumour necrosis factor a production in trinitrobenzenesulphonic acid induced colitis. Gut. 1997;41(4):487-93. https://doi.org/10.1136/gut.41.4.487 PMid:9391247

19. Yalçin SS, Yurdakok K, Tezcan I, Öner L. Effect of glutamine supplementation on diarrhea, interleukin-8 and secretory immunoglobulin $a$ in children with acute diarrhea. J Pediatr Gastroenterol Nutr. 2004;38:494-501. https://doi. org/10.1097/00005176-200405000-00007

PMid:15097437 